\title{
Recessions and a changing theoretical basis of the recoveries: a view from the state-corporation hegemonic stability theory
}

\author{
Recessões e uma mudança na base teórica \\ das recuperações: uma visão da teoria da \\ estabilidade hegemônica da corporação estatal
}

DARIUSZ ELIGIUSZ STASZCZAK*

\begin{abstract}
RESUMO: Este artigo analisa as razões das recessões mundiais em 1974-1975, 1980-1982 e 2008-2009 e métodos para melhorar a economia baseando-se em várias teorias da macroeconomia e de acordo com a visão da teoria da estabilidade hegemônica da corporação estatal. Várias razões práticas das três recessões modernas (isto é, os choques do petróleo e a bolha da especulação) e várias atividades governamentais para recuperar a economia explicam a mudança de posições dos estados e das corporações transnacionais no sistema global. Governantes políticos baseados em teorias desenvolvimentistas ou liberais da macroeconomia de forma intercambiável. A crescente importância das corporações transnacionais e suas influências na teoria das recuperações confirmam a correção da teoria da estabilidade hegemônica da corporação estatal.

PALAVRAS-CHAVE: crise econômica e financeira global; recessões mundiais; choques do petróleo; bolha da especulação; teoria Keynesiana; curva de Phillips; teoria monetária; teoria da economia do lado da oferta; teoria da estabilidade hegemônica da corporação estatal.

ABSTRACT: This paper analyses reasons of the world recessions in 1974-1975, 1980-1982 and 2008-2009 and methods to improve the economy basing on various theories of macroeconomics and according to the view from the theory of the state-corporation hegemonic stability. Various practical reasons of the three modern recessions (i.e., oil shocks and the speculation bubble) and various governmental activities to recover the economy explain changing positions of states and transnational corporations in the global system. Ruling politicians based on developmental or liberal theories of macroeconomics interchangeably. Growing importance of transnational corporations and their influences on theory of recoveries confirm the correctness of the state-corporation hegemonic stability theory.
\end{abstract}

\footnotetext{
* Dariusz Eligiusz Staszczak, John Paul II Catholic University of Lublin, Lublin, Poland. Orcid 0000-0003-1228-8841. E-mail: staszczak@kul.lublin.pl. Submitted: 2/January/2019; Approved: $1 /$ February/2019.
} 
KEYWORDS: Global economic and financial crisis; world recessions; oil shocks; speculation bubble; Keynesian theory; Phillips curve; monetary theory; theory of supply-side economics; theory of state-corporation hegemonic stability.

JEL Classification: E42; E52; F02; F63.

\section{INTRODUCTION, HYPOTHESIS AND THEORETICAL BACKGROUND}

The global recessions usually create new thinking about the economy and break stereotypes. Contradictions between liberal and developmental approaches to the governmental economic policy are illustrated by the clash between John M. Keynes and Friedrich Hayek (Wapshott, 2011). The Great Depression of 1929-1933 promoted Keynesian theory to obtain a dominating position. Hayek criticized the developmental and planned economies. He said: "And although all sorts of interests are now trying to re-establish under this flag privileges which the liberal era swept away, it is socialist propaganda for playing which has restored to respectability among liberal-minded people opposition to competition, and which has effectively lulled the healthy suspicion which any attempt to smother competition used to arouse" (Hayek, 2006, [1944]: 4). However, Hayek forgets about a strongly limited competition between oligopolistic corporations that can conduct to establish the cartels. In this way, cartels eliminate competition among their members. Therefore, a development of cartels is the real path to the serfdom of consumers.

In opposition to Hayek's view, Keynes demonstrated a necessity of governmental intervention during recession in the unstable market economy. He shows that market equilibrium not always means that the economic situation is well. Moreover, the recession can deepen without any governmental intervention. Keynes (2007, [1936]: 98) said that "[...] a fall in employment and income once started, might proceed to extreme lengths." Therefore, according to his opinion an increase of the level of unemployment should force governments for intervention, e.g., by spending borrowed money that is connected with a growing budgetary deficit or by reliefs for workless people "out of borrowed money." Michal Kalecki (1943) also stressed that "[...] even in capitalist system, full employment may be secured by a government spending programme, provided there is in existence adequate plant to employ all existing labour power, and provided adequate supplies of necessary foreign raw materials may be obtained in exchange for exports."

The liberal ideas had been withdrawn from the mainstream of economic reforms. Developmental ideology was maintained during the recession of 1974-1975. A return to the liberalism in mostly monetary version was possible during the recession of 1980-1982 that gave an opportunity for Reaganomics. However, liberalism had not been withdrawn from the mainstream of economic reforms during recession of 2008-2009 and in spite of a return of the recession and stagnation in many countries in the beginning of 2011 and later. Moreover, there did not exist any totally liberal approach because of the governmental supports for strongest corpo- 
rations producing a military equipment during Reaganomics and for biggest banks during the recession in 2008-2009. In this way, there are developmental elements in the formally liberal economic politics.

Therefore, I will prove the hypothesis that the global system is changing because of the growth of political importance of transnational corporations, including international banks, and that there exists the global collective hegemony of state powers and transnational corporations according to the theory of the state-corporation hegemonic stability. This theory is connected with the paradigm of the global economy, named the global political-economic spiral, and it stresses a subordination of developing states and small business to the interests of the global collective hegemony that stabilizes the world system. However, this theory acknowledges also disturbances in the world economy caused by contradictory interests between the hegemony members, i.e., inside the hegemony, e.g., between state-powers of the ideological West (e.g., the U.S.A., Germany, France, Britain) and Russia or China or between state-powers and transnational corporations (see Staszczak, 2002 and 2011).

\section{AIM AND METHODOLOGY}

The aim is to find reasons for changes of a theoretical basis of the governmental economic policies during particular recessions. The methodology is a describing analysis basing on statistical data and including dominating theories of macroeconomics. The analysis involves the highest developed countries over the world. The economic recessions and recoveries are illustrated by statistical data. Changes of governments' economic policy are described as a struggle between the developmental and liberal ideologies. The interpretation of results bases on the state-corporation hegemonic stability theory.

\section{REASONS OF THE RECESSION IN 1974-1975}

\section{AND A THEORETICAL BASIS OF THE RECOVERY}

The first oil shock in 1973-1974 caused the global recession in 1974-1975 (changes in the U.S. real GDP achieved $-0.5 \%$ in 1974 and $-0.2 \%$ in 1975 and the U.S. civilian unemployment rate achieved $8.5 \%$ in $1975-$ Economic, 2015). It was a reaction of Organization of Petroleum Exporting Countries (OPEC) for American and Dutch support to Israel against Egypt and Syria during the war in 1973. OPEC reduced sales of oil. As a result, there were deficits of the oil in the U.S.A. and in many countries of Western Europe and the oil price amounting to approximately 2.10 dollars per barrel in 1973 rose to more than 8 dollars per barrel in 1974 (Coffey, 1974; Ikenberry ed., 1988; Johnson, 1991).

Keynesian theory and a lack of belief in a self-adjusting free market economy (Keynes, 2007 [1936]) dominated in this period. Therefore, in the aim to improve the economy, the U.S. and Western European economic policy used Alban W. Phil- 
lips curve that was connected with Keynesian theory and that illustrated the reverse relation between money wage rates and unemployment rates in Britain. Moreover, Phillips indicated that in 1950 and 1953-1957 "the actual wage increase was almost exactly equal to the demand element. Thus [...], there seems to have been pure demand inflation." In this way Phillips showed reverse relation between inflation rates and unemployment rates (Phillips, 1958).

The high inflation rates in the U.S.A. amounting to $6.16 \%$ in $1973,11.03 \%$ in 1974 and $9.20 \%$ in 1975 - Inflation, 2014) and in Western Europe in 1973-1975 were helpful for the global economic recovery. Moreover, the U.S.A. accepted a slow depreciation of American dollar exchange rate in 1973-1980 because of the fact that the oil prices were expressed in the U.S. currency, i.e., weaker dollar meant cheaper oil (Kegley and Wittkopf eds., 1983). There were depreciations of the U.S. dollar versus major currencies as follows: $35 \%$ versus German mark, $13 \%$ versus Japanese yen, and $6 \%$ versus French franc but there was an appreciation of the U.S. currency versus British pound about $6 \%$ (Staszczak, 2015). In this way, the global economy recovered in 1976-1979 (changes in the U.S. real GDP achieved 3.2\%$-5.6 \%$ annually and the U.S. civilian unemployment rate dropped slowly from $7.7 \%$ to $5.8 \%$ - Economic, 2015). It was connected with a big growth of U.S. inflation rates (from $5.75 \%$ to $11.22 \%$ - Inflation, 2014).

A similar situation of high inflation was in Britain and France. French inflation rates were high in 1970s and achieved $13.7 \%$ in 1974 and $11.8 \%$ in 1975, next dropped to $9.1 \%$ in 1978 and rose to $10.8 \%$ in 1979, (France, 2015). British inflation rates were extremely high and amounted to $16.0 \%$ in 1974 and $24.2 \%$ in 1975 , next decreased to $8.3 \%$ in 1978 and increased to $13.4 \%$ in 1979 (Historical UK, 2015).

The Keynesian theory was not discarded and its simplistic version named Phillips curve was used to recover the economy. Governmental interventionism was a basis of economic reforms. Moreover, détente period in the U.S.A.-U.S.S.R. relations promoted the peaceful growth of the economy. The growth of the importance of transnational corporations was possible because of a liberalization of international trade and capital flows that promoted the globalization process (Staszczak, 2012). Developmental policies were profitable for corporations because of a promotion of higher demand for their commodities. Higher inflation and governmental expenditure promoted the recovery for the economy.

A different situation was in Germany after the collapse of the first Bretton Woods system, i.e., fixed (rigid) exchange rate system. During the end of this system Bundesbank strongly supported the dropping exchange rates of the U.S dollar and German foreign reserves increased by 40.9 German marks from 1970 to May 1971. It was a big growth compared to the reserve increase of 14.9 billion German marks from January 1968 to September 1969. Since March 1971, i.e., the beginning of the floating exchange rate system Bundesbank had not been obliged to intervene. Therefore, Bundesbank obtained new opportunities for more independent monetary policy and tried to control monetary expansion and inflation since 1974. However, it was a difficult task because of the first oil shock and inflationary pressure. German inflation rate achieved 5.9\% in 1975 (and it was close to the U.S. inflation 
rate in this year) but German inflation rates dropped from 4.3\% in 1976 to $2.7 \%$ in 1979 (whereas U.S. inflation rates rose during this period) (Issing, 2005). A worse situation was in Japan because of the highest inflation rate that amounted to $23.10 \%$ in 1974 but dropped to $11.80 \%$ in 1975 and to $3.80 \%$ in 1979 , (Historical, Japan, 2015). A restrictive monetary policy had been applied in Japan. Therefore, in the late 1970s and early 1980s, Japanese and German inflation rates were lower than in many other countries. In this way these two countries withdrew Phillips curve from their economic policies faster than other states. Such a situation was connected with a lack of a belief in Phillips curve by German and Japanese policy makers. German Finance Minister Shiller and Bundesbank President Klasen did not believe to solve unemployment through higher inflation in the 1970s. Japanese Finance Minister Fukuda accepted the inflation rate by $4-5 \%$ as a necessity to maintain the economic growth in 1970 (Nelson, 2006).

\section{REASONS OF THE RECESSION IN 1980-1982 AND A THEORETICAL BASIS OF THE RECOVERY}

The second oil shock in 1979-1980, i.e., the big growth of the oil prices caused the next recession in 1980 and in 1982 (changes in the real U.S. GDP achieved $-0.2 \%$ and $-1.9 \%$ and the U.S. civilian unemployment rate achieved $7.1 \%$ and $9.7 \%$ respectively), except the small economic recovery in 1981 (a change in the real U.S. GDP achieved 2.6\%) (Economic, 2015). This shock was connected with the disruption in Iranian oil production caused by the revolution in Iran in 1978-1979 and the reduction of oil production by Saudi Arabia. In result the oil price increased from 19 dollars per barrel to 31 dollars per barrel in the early months of 1979 (Ikenberry ed., 1988).

In the beginning of the recession the Phillips curve was still used in the economic policy that forced the extreme high growth of inflation (the U.S. annual inflation rate achieved $13,58 \%$ in 1980 - Inflation, 2014) in the aim to recover the economy and to reduce the unemployment rates. However, this policy was not successful and caused a loss of the people's faith in the fiat money. People tried to spend money for unnecessary products because of a big growth of inflation rates. A similar situation of high annual inflation rates by $13.6 \%$ in France (France, 2015) and $18 \%$ in Britain in 1980 (Historical, UK, 2015) confirmed the use of the Phillips curve by the policy makers in these countries. However, Germany maintained relatively low inflation rates by $5.45 \%$ in $1980,6.32 \%$ in 1981 and $5.26 \%$ in 1982 , (Germany, Inflation, 2015) in the aim to avoid the overprotection in the economy. Japanese inflation rate by $7.80 \%$ in 1980 dropped to $4.90 \%$ in 1981 and to $2.70 \%$ in 1982, (Historical, Japan, 2015). Ruling politicians in Germany and Japan did not believe in the Phillips long run trade-off between inflation and unemployment rates and they tried to moderate inflation for a steady economic growth (Nelson, 2006). The overprotection in the economy did not cause any positive effects in the 
U.S.A. and in other countries because a growth of inflation rates was connected with a growth (not a decrease) of unemployment rate and with the recession.

In this way the U.S. president Ronald Reagan began a new economic policy named Reaganomics that was a return to the liberal ideas but in the new form. Liberal ideas, i.e., neo-classic theories were dominating ideas in the U.S.A. until the Great Depression in 1929-1933. These theories stressed a big importance of the free market and explained inefficiency of governmental intervention in the economy. However, a volume of money in a circulation and inflation rate were not important indicators for neo-classics but U.S. dollar convertibility into the gold according to the fixed parity reduced inflation rates till 1933. From 1933 to 1981 the U.S. economic policy based on Keynesian theory and Phillips curve. The developmental (protectionist) theories could be applied to the real economy after the cancelation of the fixed gold parity of the U.S. currency in 1933. In this way, fiat (valueless) money promoted high governmental expenditure and high inflation rates (see Staszczak, 2015). Theoretical basis of Reaganomics consisted of the monetary theory (monetarism) and the theory of the supply-side economics mostly.

The monetary theory of Milton Friedman disagrees with the Keynesian theory and the Phillips because of its big importance to restrain inflation and a lack of belief in any positive effects of the governmental intervention in the economy. Monetarists underline a necessity of limited inflation and a lack of governmental activity in the economy. They require a slow growth of (fiat) money into the circulation because there was not any fixed gold parity to reduce inflation. Friedman said (in interview for Newsweek on 12 November 1979) as follows: "Orthodox wisdom has it that unemployment is a cure for inflation. A minority has it that unemployment causes inflation. Both views arte half-truths" (Nelson, 2006). An importance of the volume of money in circulation differentiates the monetary theory from other liberal theories, especially from neo-classics. However, a limitation of governmental activity in the economy is a characteristic view for all liberal theories.

Reaganomics based on fiat money that was not connected with any fixed gold or silver parity since the Nixon shock, i.e., the cancellation (the suspension in the formal language) of the U.S. dollar convertibility into gold in 1971 (Coffey, 1974). According to the Keynesian theory, a growth of governmental expenditure, i.e., a growth of money in circulation, is helpful for the economy in the recession times. Therefore, Keynes stresses the importance of the monetary economy as follows: "Money in its significant attributes is, above all, a subtle device for linking the present to the future; and we cannot even begin to discuss the effect of changing expectations on current activities except in monetary terms. We cannot get rid of money even by abolishing gold and silver and legal tender instruments. So long as there exists any durable asset, it is capable of possessing monetary attributes and therefore, of giving rise to the characteristic problems of a monetary economy" (Keynes, 2007, [1936]: 186). In opposite view, Friedman also discusses the economic policy implications within the frameworks of fiat money standard. He claims as follows: "The real quantity of money is the quantity expressed in terms of the volume of goods and services the money will purchase" and that "the price of money is the quantity of 
goods and services that must be given up to acquire a unit of money - the inverse of the price level. [...] The price of money is not the interest rate, which is the price of credit. [...] Of course, the interest rate may affect the quantity of money demanded [...]" (Friedman, 1987). Friedman critics the Keynesian money spending by business and government "which is independent of current income." He also critics "the Keynesian policy of keeping interest rates very low." In his opinion "...wherever the cheap money policy was tried, it led to inflation and had to be abandoned," (Friedman, 1970). The most effective achievement of Friedman was his critics of the Phillips trade-off. He stressed that "the phenomenon of simultaneous high inflation and high unemployment increasingly forced itself in public and professional notice, receiving the unlovely label of stagflation," (Friedman, 1976).

Moreover, the supply-side economics presented by Robert A. Mundell, Arthur Laffer, Jack Kemp and Jude Wanniski had been used by Ronald Reagan together with the monetarism. The most important idea was to decrease tax rates in the aim to stimulate the economic growth by incentives for work and investment. There was also planned an increase of government revenues in the longer time period (Coy, 1999). Arthur Laffer (2004) illustrates the theory of supply-side economics by the Laffer curve which shows that "[...] there are two tax rates that will collect the same amount if revenue: a high tax rate on a small tax base and a low tax rate on a large tax base." Laffer (2004) shows "[...] the positive impact that lower tax rates have on work, output, and employment [...]" and that tax rate cut can cause a growth or drop of revenues. It depends on "the tax system in place, the time period being considered, the ease of movement into underground activities, the level of tax rates already in place, the prevalence of legal and accounting-driven tax loopholes, and the proclivities of the productive factors." Moreover, Laffer (2004) stresses an importance of reduced government expenditures for social welfare programs because of lower unemployment and higher people incomes.

In accordance with presumptions of the monetary theory, a limited growth of money into circulation was the integral element of Reaganomics which caused that the U.S. annual inflation rates dropped by $3.22-4.30 \%$ in 1983-1985. Inflation rates were relatively low and amounted to $1.91-4.83 \%$ in 1986-1989 (Inflation, 2014). Low inflation rates in 1983-1989 were characteristic for many countries and achieved from $-0.12 \%$ (deflation) to $3.28 \%$ in Germany (Germany, Inflation, 2015), 2.7\%-9.6\% in France (France, Inflation, 2015) and 3.4\%-6.1\% in Britain, (Historical, UK, 2015).

Low inflation and a big demand for the U.S. dollar, i.e., a currency in which the oil prices were presented in the world markets (Johnson, 1991) promoted to strengthen the U.S. dollar exchange rates about $62 \%$ versus German mark, 79\% versus British pound, $113 \%$ versus French franc and 5\% versus Japanese yen in 1980-1985, i.e., during the first part of Reaganomics. However, the U.S. dollar was depreciated about 36\% versus German mark, 21\% versus British pound, 29\% versus French franc and $42 \%$ versus Japanese yen in 1985-1989, i.e., during the second part of Reaganomics (Staszczak, 2015) because of the negative effects of Reaganomics, i.e., the problems with the growing deficits on the U.S. balances on foreign trade and on 
current account that exceeded 100 billion dollars since 1984. The deficit on the U.S. foreign trade balance rose from 16.17 billion dollars in 1981 to 151.16 billion dollars in 1987 and dropped to 93.14 billion dollars in 1989. The surplus on the U.S. balance on current account amounted to 5.03 billion dollars in 1981 was changed into deficit amounted to 5.54 billion dollars in 1982 and rose to 160.65 billion dollars in 1987 and fell to 99.49 billion dollars in 1989 (Economic, 2013).

According to the theory of supply-side economics, the U.S.A. introduced the Economic Recovery Tax Act (ERTA, also named the Kemp-Roth Tax Cut) in August 1981. In result, the highest marginal tax rate on unearned income decreased from $70 \%$ in 1981 to $50 \%$ in 1984 and to $28 \%$ in 1988 . In spite of this tax cuts, the personal income taxes paid by highest incoming people rose between 1980 and 1984. The marginal earned income tax rates lowered by $25 \%$ in 1981-1983. In result, federal income tax revenue rose by $2.7 \%$ annually and total government income tax revenue rose by $3.5 \%$ annually in 1983-1986. The above mentioned data confirmed the positive effects of tax cuts for the U.S. economy according to the Laffer curve, (Laffer, 2004). It was connected with the below illustrated growth of the real U.S. GDP (Gross Domestic Product) and a drop of the U.S. civilian unemployment rate from $9.7 \%$ in 1982 to $5.3 \%$ in 1989 (Economic, 2015).

Economic reforms overcame the recession. Changes in the real U.S. GDP achieved $4.6 \%$ in $1983,7.3 \%$ in 1984 and $4.2 \%$ in 1985 . The lower economic growth was in 1986-1987 and changes in the real U.S. GDP achieved 3.5\% but during a higher economic growth in 1988 and 1989 changes in the real U.S. GDP achieved $4.2 \%$ and $3.7 \%$ (Economic, 2015).

However, Reaganomics was influenced by the second cold war between the U.S.A. and the U.S.S.R. in the 1980s caused by Soviet invasion in Afghanistan in 1979 and war state in Poland in 1981 (Smith, 1992). Therefore, Reaganomics was connected with the armaments race aiming at attainment of military advantage over the U.S.S.R. The armament race caused a big growth of governmental military spending. It was an unofficial element of Keynesian theory in Reaganomics that promoted the above-mentioned growth of the real GDP but caused the big growth of budget deficits from 73.9 billion dollars in 1981 to 237.9 billion dollars in 1986 (Economic, 2015), in spite of the above-mentioned growth of the federal income according to the Laffer presumptions.

In this way, the contradictory monetarist and Keynesian theories were used simultaneously. Of course, Reaganomics was profitable for transnational corporations because it let them to obtain higher profits because of lower taxes and decreased governmental control of their activities and higher government's military spending. Therefore, Reaganomics was a step to construct the global collective hegemony of state-powers and transnational corporation. The economic recovery was transferred from the U.S.A. to Western Europe and Japan that strengthened the liberal system and transnational corporations.

The collapse of communism in the Eastern and Central Europe in 1989-1991 promoted next expansion of transnational corporations and monetarist theory as a basis of economic reforms in post-communist countries in spite of total inade- 
quacy of monetarism to their centrally planned economies. Such a situation connected with decreasing role of the U.S.A. in the global system promoted to establish the global collective hegemony of state-powers and transnational corporations since the second half of the 1990s (see Staszczak, 2011).

The U.S. slower economic growth in 1990 and the small recession in 1991 (changes in the U.S. real GDP achieved $-0.1 \%$ - Economic, 2015) promoted a higher inflation rate achieved 4.25\%) (Inflation, 2014). A destruction of the communist systems in Europe in 1989-1991 caused the second détente period between ideological West and Russia. There was also the economic growth in 1992-2000 (changes in the real U.S. GDP achieved 2.7\%-4.8\% annually) and the U.S. inflation rates were relatively low and amounted to $1.55-3.38 \%$. The above mentioned facts confirm a continuation of the monetary policy.

Asian recession in the second half of the 1990s caused the economic stagnancy in the U.S.A. in 2001 (changes in the real U.S. GDP achieved 1.0\% - Economic, 2015) and the small recession in some European countries, e.g., in Germany (changes in real German GDP achieved $-0.7 \%$ in 2003 - Eurostat, 2015). This stagnancy and recession did not change the dominating economic theory and annual inflation rate amounted to $2.83 \%$, in 2001 in the U.S.A. (Inflation, 2014) and $1.03 \%$ in 2003 in Germany (Inflation, Germany, 2015). Moreover, the economic recession in Asia (that affected the U.S. and European economies in a smaller scale), caused more attractive opportunities to invest in Asia. However, the fact that Asian recession affected the U.S.A. and Europe proves the change in the global hegemony from the American hegemony to the collective hegemony according to state-corporation hegemonic stability theory (Staszczak, 2011).

A slow economic growth was maintained in the U.S.A. in 2002-2007. Changes in the real U.S. GDP achieved $1.8 \%$ in 2002 and had a growing tendency to 2004 when achieved $3.8 \%$ and later a dropping tendency when changes achieved again $1.8 \%$ in 2007 (Economic, 2015). The U.S. annual inflation rates were relatively low by $1.59-3.39 \%$ (Inflation, 2014). A similar slow economic growth existed in Europe with some movements in the time period, e.g., changes in real German GDP achieved $1.2 \%$ in 2004, 3.7\% in 2006 and $1.1 \%$ in 2008 (Eurostat, 2015). German annual inflation rates were also relatively low by $1.79 \%$ in 2004 and $2.75 \%$ in 2008 (Inflation, Germany, 2015). Such a situation proves a practical use of the monetarist theory in the U.S. and European, mostly German economic policies. International system altered during this period because of the growing economic and political importance of China, Russia, India, Brazil and other countries that also confirms the state-corporation hegemonic stability theory (Staszczak, 2011).

\section{REASONS OF THE RECESSION IN 2008-2009 AND A THEOTRETICAL BASIS OF THE RECOVERY}

The speculative bubble (i.e., bad credits, overvalued real estates, stocks, etc.) made by global banks was the most important reason of the recession in 2008-2009. 
An additional reason was the third oil shock (i.e., a big growth of oil prices) made by OPEC in 2008. Changes in the U.S. real GDP rate achieved $-0.3 \%$ and $-2.8 \%$ and the U.S. civilian unemployment rate increased to $5.8 \%$ and $9.3 \%$ (Economic, 2015). The recession had the global range and caused a very difficult situation in state-powers and in other countries. Changes in the real GDP rates achieved $-5.6 \%$ in Germany, $-2.9 \%$ in France and $-4.3 \%$ in Britain in 2009 (Eurostat, 2015). Moreover, this recession did not finish definitely in 2009. The real U.S. GDP rate that achieved $1.6 \%$ during the whole year 2011 but in the first quarter the changes achieved $-1.5 \%$ so it was a drop of the real GDP, i.e., a continuation of the recession (Economic, 2015). Moreover, there was a stagflation in Europe in a long time period because of a low increase in the real GDP rates by $0.4 \%$ in 2012 and $0.1 \%$ in 2013 in Germany, by $0.2 \%$ in 2012, 0.7\% in 2013 and $0.2 \%$ in 2014 in France and by $0.7 \%$ in 2012 in Britain. The recession did not finish in 2009 in many weaker countries, e.g., Greece, Spain, Portugal, Italy and Cyprus. The recession in these countries remained from three to seven years (Eurostat, 2015).

Moreover, the third oil shock in 2008 promoted big trade deficit in fuels of the majority of EU countries. EU countries are traditional net importers of oil and other fuels. However, the third oil shock, i.e., a reduction of oil production by OPEC caused a big growth of oil prices. Therefore, EU and other countries paid more money for fuels (Staszczak, 2017). As a result, higher costs of production in connection with lower demand promoted a drop of volume of manufactured goods, i.e., a recession in many countries. A low demand for goods and services resulted from the restrictive monetary policy (in accordance with the monetarist requirements) and the necessity to get out of debts by customers and business. High debts were results of speculative bubble that was made by international banks. Bankrupting banks asked for a public help. Such a situation proves a total inadequacy of the liberal methods for the recovery and a lack of responsible ideas of policy makers.

A domination of monetary theory as the major theoretical basis for the recovery proved relatively low annual inflation rates in 2008-2009, that achieved as follows: $3.85 \%$ and $-0.34 \%$ (deflation) in the U.S.A. (Inflation, 2014), $2.75 \%$ and $0.23 \%$ in Germany (Germany, Inflation, 2015), $2.8 \%$ and $0.1 \%$ in France (France, 2015), 3.60\% and $2.10 \%$ in Britain (Historical, UK, 2015), $1.40 \%$ and $-1.40 \%$ (deflation) in Japan (Historical, Japan, 2015). Such a situation was connected with a limited growth of money into a circulation according to monetarist requirements.

A difference between monetarist and Keynesian theories in practice can be illustrated by inflation rates because Keynes suggests a growth of governmental expenditure during recession but Friedman requires a slow growth of money into a circulation. Therefore, high inflation rates were characteristic indicators during the recession in 1974-1975 as the results to use Keynesian theory and Phillips curve in the aim to recover the economy. In opposite view, low inflation rates were characteristic indicators during the recession in 2008-2009 as the results to use monetarist theory in the same aim.

A lack of will of the policy makers to improve the economy through using a less restrictive monetary policy confirmed a low level of annual inflation rates after 
the recession as follows: $1.47 \%-3.16 \%$ in the U.S.A. in 2010-2013 (Inflation, 2014), $1.15 \%$ in Germany in 2010 (Germany, Inflation, 2015), 0.5\%-2.1\% in France in 2010-2014 (France, 2015), 2.83\%-4.48\% in Britain in 2010-2012 (Historical, UK, 2015 ) and from $-0.70 \%$ (deflation) to $0.30 \%$ in Japan in 2010-2013 (Historical, Japan, 2015). German policy makers promoted a hard monetary policy, i.e., a strongly limited growth of money into circulation in euro zone that caused a very difficult economic situation in weaker countries, e.g., Greece, Spain and Portugal. The bankruptcy of Greece in July 2015 confirmed the big scale of the problem.

However, there were some attempts to change the monetary policy but in not the best way. Nicolas Wapshott (2011) claimed: "President George W. Bush, an ostensible adherent of Hayek's views on the sanctity of the free market, was faced with a stark choice: to watch while the market came to rest with a depression that might rival the one of nearly eighty years before, or speedily adopt Keynesian remedies to spend trillions of borrowed government dollars the sinking economy from more harm. So alarming was the prospect of letting the free market do its worst that with barely a second thought, Bush abandoned Hayek and embraced Keynes." Barack Obama continued public help for bankrupting banks. However, corporations' lobby, e.g., Tea Party represented by Sarah Palin forced a limitation of public interventions and a return to Hayek's ideas because of the growing public debt (Wapshott, 2011). In this way the public help was limited to biggest private banks. It was a totally contradictory movement according to the both liberal and Keynesian ideologies. Keynes claims that growth of government spending should cause the growing demand that will be helpful to reduce the unemployment (Keynes 2007 [1936]). However, Keynes did not ask about the public rescue for bankrupting banks. Moreover, neo-liberals stress that the economy determines politics because of the inherent rationality of corporations' activities (Tooze in McGrew and Lewis eds., 1993). However, the speculative bubble shows incompetent activities of global banks and totally irrational governmental help for them.

The speculative bubble was possible because of a limitation of governments' control over transnational corporations, mostly international banks activities and because of politicians' dependency on corporations financial and other support for their election campaigns. The recession discredited Hayek and Friedman theories and liberal limitations of governmental intervention in the economy, including a lack of control over the banks' activities. Therefore, a big change of the economic policy should be made over the world. However, strengthened corporations, including banks being members of global collective hegemony, forced governments to maintain the liberal economic policy with a strange correction, i.e., the public help for bankrupting banks. Such a situation proves the maintenance of the collective hegemony of state-powers and transnational corporations. According to the statecorporation hegemonic stability theory, a change of the economic policy is possible only within the framework of the agreement between members of the global collective hegemony.

The global collective hegemony is dominated by ineffective liberal ideas. Such ideas were promoted by the U.S.A. mostly. After the second world war, the U.S. 
economy was the strongest over the world and therefore, free market system and relatively free international trade was advantageous for this country. Developing countries were forced to put liberal theories into practice according to the theory of the state-corporation hegemonic stability. Deficits in the U.S. foreign trade since the 1970s promoted unofficial protectionist changes in the U.S. economic policy but liberal ideology was still promoted officially (Staszczak, 2011; Staszczak, 2012). However, the protectionist practices in the U.S. foreign trade since 2018 can change this situation because other countries are forced to use trade barriers. Nowadays, not only developing countries are interested to protect their domestic economies.

However, there are various and contradictive interests in the global collective hegemony, e.g., between the U.S.A., China and Russia. Moreover, transnational corporations, including banks, do not agree for a higher governmental control and for interventions in economies of particular countries and in the world economy. A power of corporations is connected with their legal or illegal financing the election marketing of various politicians and parties in many countries over the world. Therefore, politicians finance banks and other corporations, e.g., armaments producers from public money, especially from public debts, regardless of a ruling party. Such a situation strengthens the global collective hegemony in the short time period that confirms the hypothesis that the global system is changing because of the growth of power and political importance of transnational corporations, including international banks, and that there exists of the global collective hegemony of state powers and transnational corporations according to the state-corporation hegemonic stability theory. However, in the long run, an ineffective management of corporations, including banks (e.g., the speculative bubble) and incorrect economic policies of particular state-powers shake pillars of the world economy and promote social demonstrations (e.g., in France in 2018). Moreover, the U.S.A. changed the liberal trade policy into the protectionism and started the trade war against EU and China during Donald Trump presidency. Such a situation proves the U.S. economic problems and contradictory interests inside the global collective hegemony of state-powers and biggest transnational corporations.

\section{CONCLUSIONS}

Fiat, i.e., valueless money gives more chances for the governmental interventions in the economy than gold money. The Great Depression and the next three big world economic recessions demonstrate a necessity of governmental interventions within some bounds. Overprotection of the economy during the second oil shock and the recession in 1980-1982 shook the Phillips curve but it did not lever the Keynesian theory as whole. Moreover, elements of the Keynesian theory were used during Reaganomics unofficially as the governmental military expenditure together with the monetary theory and supply-side economics in spite of the theoretical contradictions. The military spending delivered high profits for the armaments producers and gave them opportunities to enforce their economic positions. Similar op- 
portunities delivered a limitation of the governmental control over the speculative activity of global banks and other transnational corporations. The recession in 20082009 shook the monetary theory and the liberal belief in the self-adjusting market economy, like the Great Depression levered the liberal ideologies and gave a chance for the Keynesian theory. The governmental support for the bankrupting banks on the one hand and a maintenance of a dominating position of liberal ideologies in economic policy on the other, confirm an existence of the global collective hegemony according to the state-corporation hegemonic stability theory.

\section{REFERENCES}

Coffey, Peter 1974 The World Monetary Crisis, London: Macmillan Press.

Coy, Peter 1999, "Why Mundell Won the Nobel; For Work that Led to Euro, not for his Supply-side Theory”, Businessweek Online, October 25, http://www. businessweek.com/1999/99_43/ b3652085.htm date: May 7, 2015.

Eastwell John, Murray Milgate, and Peter Newman, eds. 1987 The New Palgrave: A Dictionary of Economics. New York: Stockton Press; and London: Macmillan.

Economic Report of the President 2013. Transmitted to the Congress together with the Annual Report of the Council of the Economic Advisers, U.S. Government Printing Office, Washington, DC, March.

Economic Report of the President 2015. Transmitted to the Congress together with the Annual Report of the Council of the Economic Advisers, U.S. Government Printing Office, Washington, DC, February.

Eurostat 2015 - http://ec.europa.eu/eurostat last update: June 9.

France-Inflation.com, 2015, Historique Inflation en France de 1900 a 2015 - http://france-inflation. com/inflation-depuis-1901.php date: April 16.

Friedman, Milton 1970, “The Counter-Revolution in Monetary Theory", IEA Occasional Paper (Institute of Economic Affairs), no. 33: 1-14.

Friedman, Milton 1976, "Inflation and Unemployment", (Nobel Memorial Lecture), Journal of Political Economy, Vol. 85, No. 3, June: 451-472.

Friedman, Milton 1987, "Quantity Theory of Money” in Eastwell John, Murray Milgate, and Peter Newman, eds., Vol. 4: 3-20.

Germany Inflation Rate (Consumer Prices), 2015 - http://www.indexmundi.com/germany/inflation_rate_(consumer_prices?html date: April 16

Hayek, Friedrich A., 2006, [1944] he Road to Serfdom. London and New York: Routledge Classics.

Historical Inflation Rates for Japan (1971 to 2014), 2015 - http://inflationdata.com/articles/historical-inflation-rates-japan-1971-2014/ date: April 16.

Historical UK Inflation Rates (Consumer Price Index), 2015 - http://www.whatsthecost.com/historic. cpi.aspx date: April 16.

Ikenberry, Gilford John [ed.] 1988 Reason of State: Oil politics and the Capacities of American Governments, Ithaca, London: Cornell University Press.

InflationData, 2014 - http://inflationdata.com/inflationdata.com/Inflation/Inflation_Rate/HistoricalInflation.aspx dated: August 20.

Issing, Otmar 2005, "Why Did the Great Inflation Not happen in Germany?”, Review (Federal Reserve bank of. St. Louis), March/April, Part 2: 329-326.

Johnson, Lynn K. 1991 America as a World Power. Foreign Policy in a Constitutional Framework, New York: McGraw-Hill.

Kalecki, Michal 1943, "Political Aspects of Full Employment”, Political Quarterly, Vol. 14, Issue 4 (October): 322-331. 
Kegley, Charles W., Jr. and Eugene R. Wittkopf, (eds.) 1983 Perspectives on American Foreign Policy, New York: St. Martin's Press.

Keynes, John M. 2007, [1936] The General Theory of Employment, Interest and Money, Basingstoke: Palgrave Macmillan.

Laffer, Arthur 2004, “The Laffer Curve: Past, Present, and Future”, Backgrounder \#1765 (The Heritage Foundation): 1-19.

- http://www.heritage.org/research/reports/2004/06/the-laffer-curve-past-present-and-future date: May 7, 2015.

McGrew, Anthony G. and Paul G. Lewis, (eds.) 1993 Global Politics, Cambridge, MA: Polity Press.

Phillips, Alban W. 1958, "The Relation between Unemployment and the Rate of Change of Money Wage Rates in the United Kingdom, 1961-1957”, Economica, New Series, Vol. 25, No. 100 (November): 283-299.

Nelson, Edward 2006, "The Great Inflation and Early Disinflation in Japan and Germany”, Working Paper (Federal Reserve Bank of St. Louis, Research Division), 2006- 052E: 1-49.

Staszczak, Dariusz Eligiusz 2002 "Global Political-economic Spiral as a Model of the World Changes", Studia Polityczne, No. 13: 329-352.

Staszczak, Dariusz Eligiusz 2011 “Theoretical Interpretations of the European Union Enlargement: Perspectives from a New Global Paradigm”, Journal of Knowledge Globalization, Vol. 4, No. 1: 71-92.

Staszczak, Dariusz Eligiusz 2012. "International Trade and Capital Flows as the Sources of the Nations Poverty or Richness”, Conference Proceedings [Knowledge Globalization Conference, Boston, Massachusetts, October 16-17, 2011, Published Annually; Sawyer School of Business; Suffolk University, Boston, Massachusetts; Conference Papers: (C) Knowledge Globalization Institute, Boston, Massachusetts, USA] 1, Vol. 5: 146-165.

Staszczak, Dariusz Eligiusz 2015 "Global Instability of Currencies. Reasons and Perspectives according to the State-corporation Hegemonic Stability Theory", Revista de Economia Politica. Brazilian Journal of Political Economy, Vol. 35, No. 1 (138): 175-198.

Staszczak, Dariusz Eligiusz 2017 "Changes of EU Countries Positions in International Trade of Mineral Fuels in 2006-2015”, Acta Scientiarum Polonorum Oeconomia, Vol. 16 (4): 151-160.

Tooze, Roger 1993. "Conceptualizing the Global Economy” [in] McGrew, Anthony G. and Paul G. Lewis, (eds.)

Wapshott, Nicolas 2011 Keynes Hayek: The Clash that Defined Modern Economics, New York, NY: W. W. Norton \& Company, Inc. 